\title{
St. Lawrence Seaway: Navigation on Gulf of Saint Lawrence Estuary and the St. Lawrence River
}

\author{
Kenneth R. Olson, Cory D. Suski \\ Department of Natural Resources, College of Agricultural, Consumer, and Environmental Sciences, University of Illinois, Urbana, \\ Illinois, USA \\ Email: krolson@illinois.edu
}

How to cite this paper: Olson, K.R. and Suski, C.D. (2020) St. Lawrence Seaway: Navigation on Gulf of Saint Lawrence Estuary and the St. Lawrence River. Journal of Water Resource and Protection, 12, 672-691. https://doi.org/10.4236/jwarp.2020.128041

Received: July 21, 2020

Accepted: August 11, 2020

Published: August 14, 2020

Copyright () 2020 by author(s) and Scientific Research Publishing Inc. This work is licensed under the Creative Commons Attribution International License (CC BY 4.0).

http://creativecommons.org/licenses/by/4.0/ (c) (i) Open Access

\begin{abstract}
The entire Great Lakes watershed drains through Lake Ontario and flows into the St. Lawrence River near Cape Vincent, New York. The St. Lawrence River then flows northeast through Quebec and Ontario and into the largest estuary in the world, the Gulf of Saint Lawrence. The St. Lawrence River, between Ontario, Canada and New York, United States is part of the international boundary. The St. Lawrence Seaway permits ocean-going vessels to go from the Great Lakes of North America to the Atlantic Ocean. Navigation of the St. Lawrence was not possible until canals were built around the Lachine Rapids near Montreal. The canals allowed ships to by-passes the rapids and travel into Lake Ontario. In 1954, the United States agreed to joint development of the international sections of the St. Lawrence River. The St. Lawrence Seaway was opened in 1959 and permits ocean-going ships to go all the way to the southwest corner of Lake Superior near Duluth, Minnesota. During WWII, German U-boats sank several merchant marine ships and three Canadian warships in the lower St. Lawrence River, the Strait of Belle Isle, Cabot Strait and the Gulf of Saint Lawrence. The bottom of the St. Lawrence River is littered with the wreckage of these ships and other ships which were lost during storms. The International Joint Commission recommended that the Canada and United States jointly improve navigation on the St. Lawrence River from Lake Ontario to Montreal. This lead to the signing of the St. Lawrence Treaty. Steel companies supported the treaties since the new St. Lawrence Seaway could get Labrador iron ore to the United States mills in the Great Lakes region. The Seaway's power dams generate 3.5 million kilowatts of electricity which is provided to industry and to thousands of consumers in the New York State, New England and parts of Canada. The electric power generated by the project would be shared equally. This paper highlights how the geological and landscape properties of the St. Lawrence River watershed were
\end{abstract}


responsible for the successful economic development of this important and historically-rich region of North America. Planned economic and urban development of the St. Lawrence River basin by USACE was blocked by the "Save the River" campaign. Environmental challenges include disposal of treated and untreated wastewater, water pollution, and shore erosion, invasive species and flooding.

\section{Keywords}

Invasive Species, Lake Champlain, Newfoundland, Shore Erosion, Water Pollution

\section{Introduction}

The St. Lawrence River watershed and Newfoundland located in Canada are currently home to millions of people. The development of this area by Europeans has roots that extend back thousands of years, and is intimately connected to the St. Lawrence basin and the eventual development as the St. Lawrence Seaway [1].

The St. Lawrence River flows $3058 \mathrm{~km}$ in a northeastern direction from Lake Ontario to the Atlantic Ocean (Figure 1) [1]. The headwater is the North River in the Mesabi Range at Hibbing, Minnesota [2], and the entire Great Lakes drainage basin discharges into the St. Lawrence River near Cape Vincent, New York.

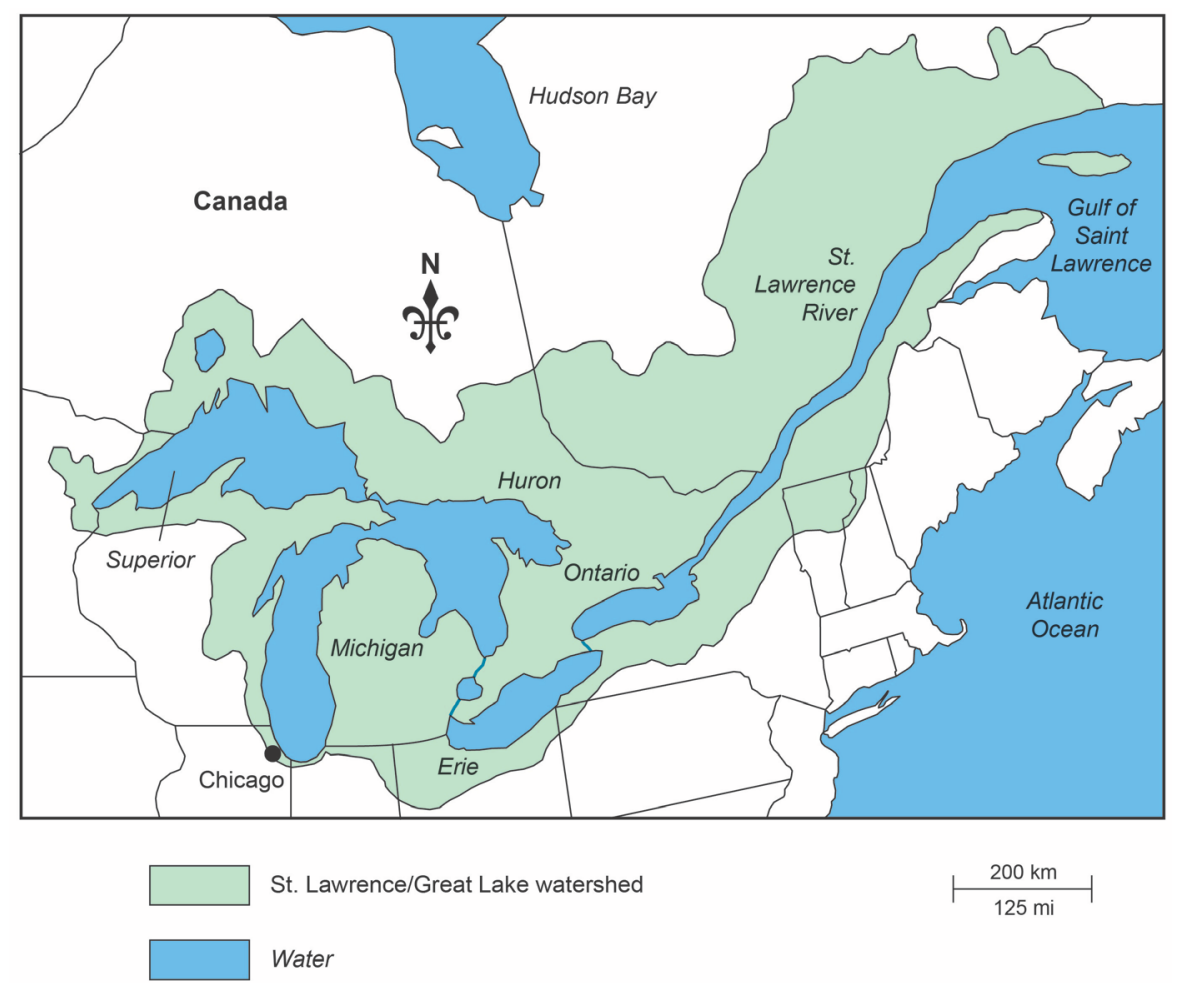

Figure 1. The Great Lakes and St. Lawrence River watershed. Map by Mic Greenberg. 
The St. Lawrence River begins at eastern end of Lake Ontario and drains to the northeast and into the Gulf of Saint Lawrence, the largest estuary in the world (Figure 2). The river is part of the international boundary between Ontario, Canada and New York, United States, flowing through the Canadian provinces of Quebec and Ontario [3]. The drainage area totals 1,344,200 $\mathrm{km}^{2}$ with more than $60 \%$ in Canada and $40 \%$ in the United States.

The St. Lawrence Seaway is a maze of canals, locks (Figure 3), and channels in the United States and Canada [2]. The Seaway permits ocean-going vessels to travel from the Atlantic Ocean to the Great Lakes of North America, as far west as Lake Superior. The Seaway is named for the St. Lawrence River. The Welland Canal (Figure 4) connects Lake Ontario to Lake Erie and permits Ocean going ships to bypass the Niagara Escarpment and Niagara Falls (Figure 5).

The St. Lawrence lowlands are plains adjacent to the St. Lawrence River between Brockville, Ontario in the west and Quebec City in the east. The lowlands include the Ottawa River valley west to Renfrew, Ontario. The topography of the lowlands is the result of weathering and erosion by rivers of the flat-lying sedimentary rock. The total lowland area is $46,000 \mathrm{~km}^{2}$ with $5000 \mathrm{~km}^{2}$ in the United States. It is $450 \mathrm{~km}$ long and $100 \mathrm{~km}$ wide in the west but narrows to $35 \mathrm{~km}$ in Quebec with an arm extending $130 \mathrm{~km}$ south into the Lake Champlain Valley (Figure 6). The lowlands were occupied by the Iroquoian-speaking people at the time of discovery by Jacques Cartier in 1535. The farmlands were

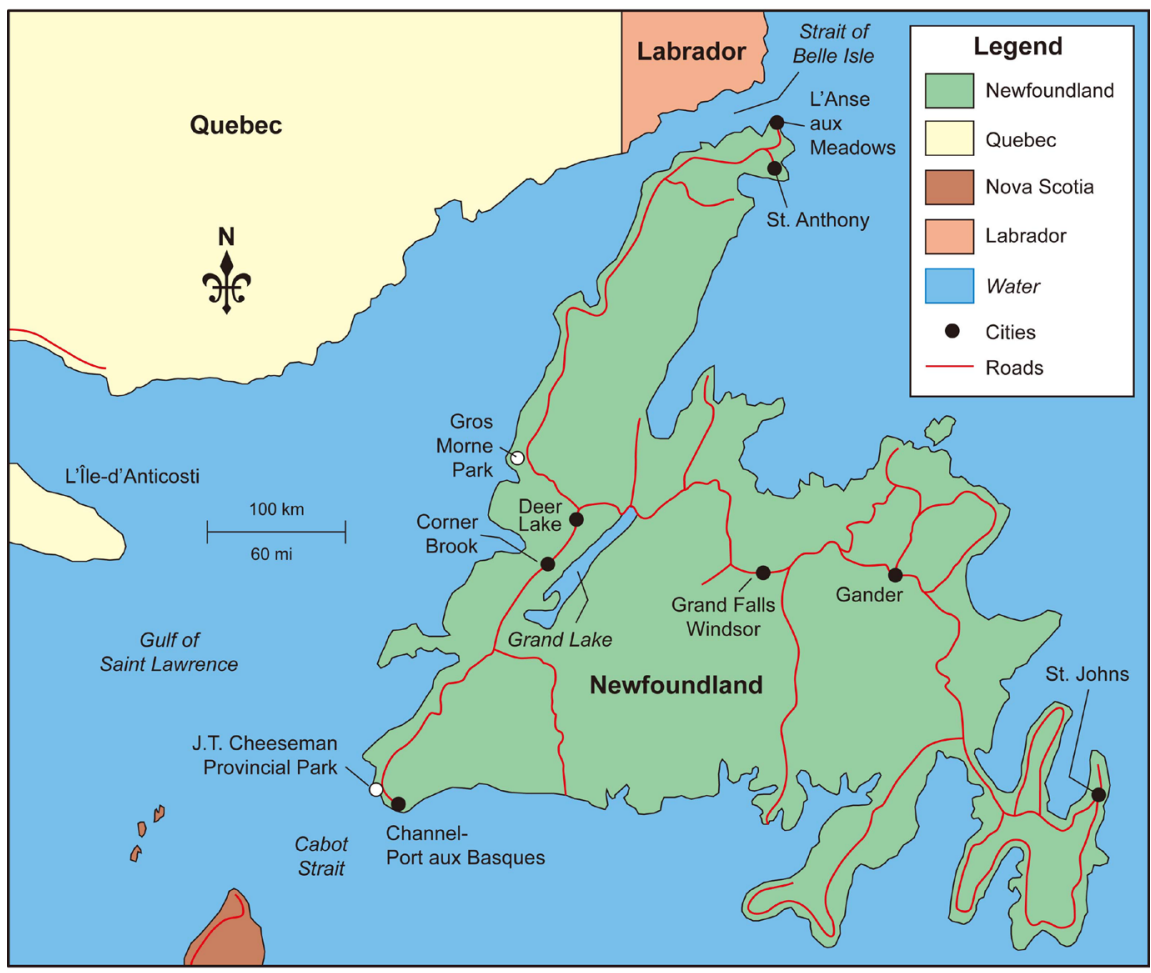

Nova Scotia

Figure 2. Newfoundland, the Gulf of St. Lawrence, the Strait of Belle Isle and Cabot Strait. Mic Greenberg. 


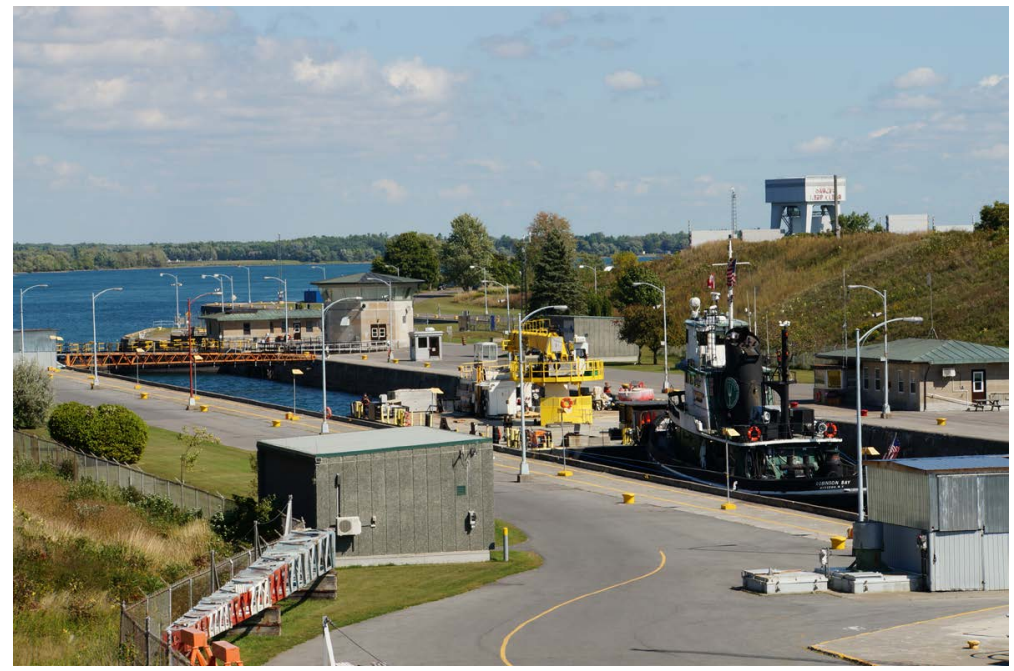

Figure 3. The Iroquois lock and control dam which controls the level of Lake Ontario. Picture taken by Lois Wright Morton.

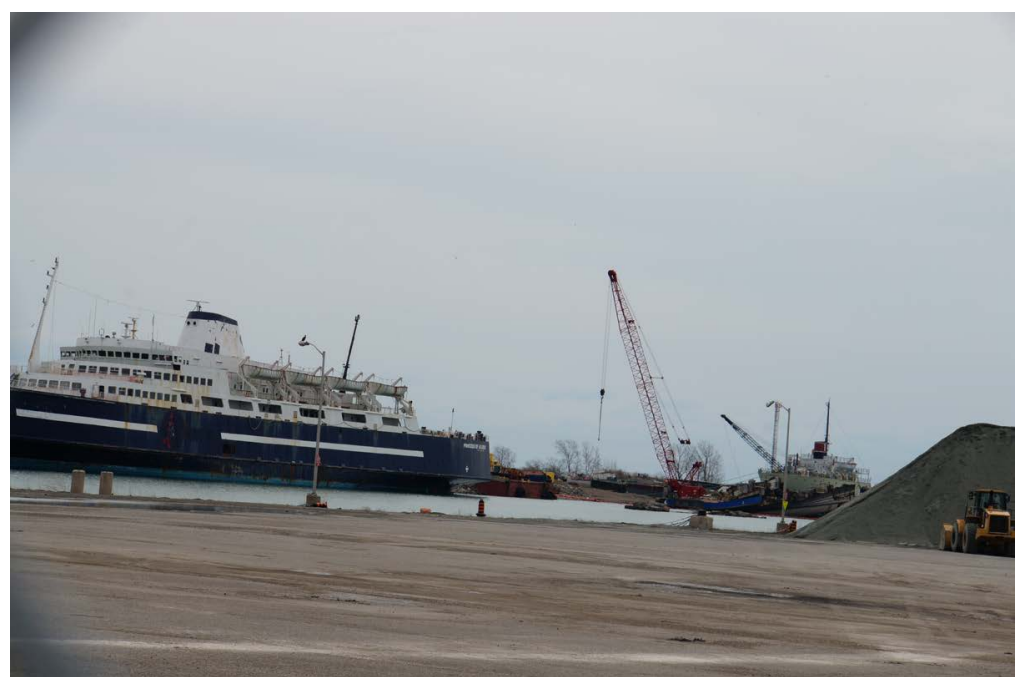

Figure 4. The Welland canal which permitted ocean going ships to by-pass the Niagara Escarpment and Niagara Falls.

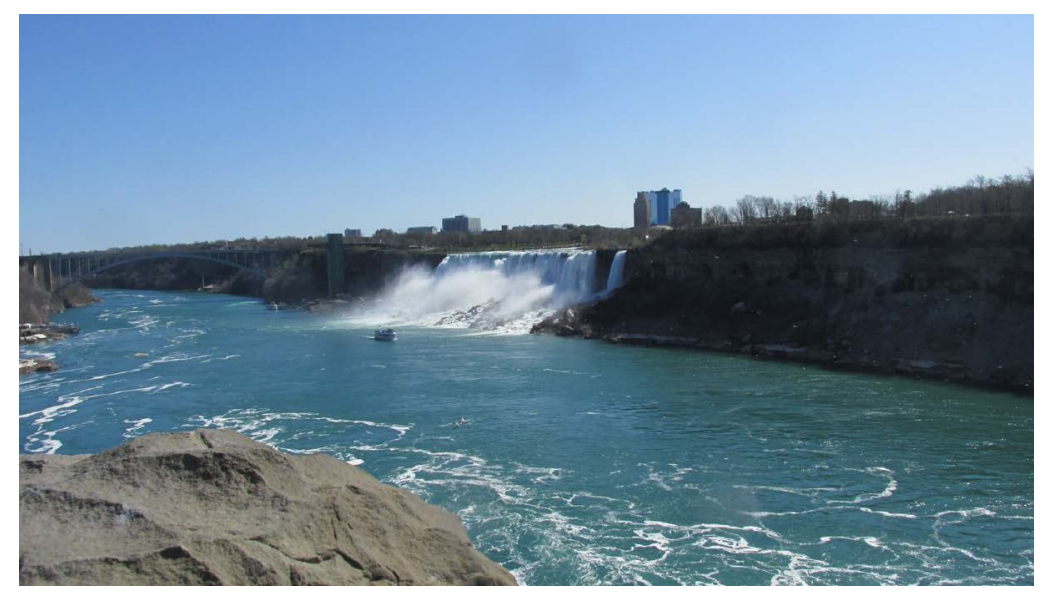

Figure 5. Niagara Falls and the Niagara Escarpment. 


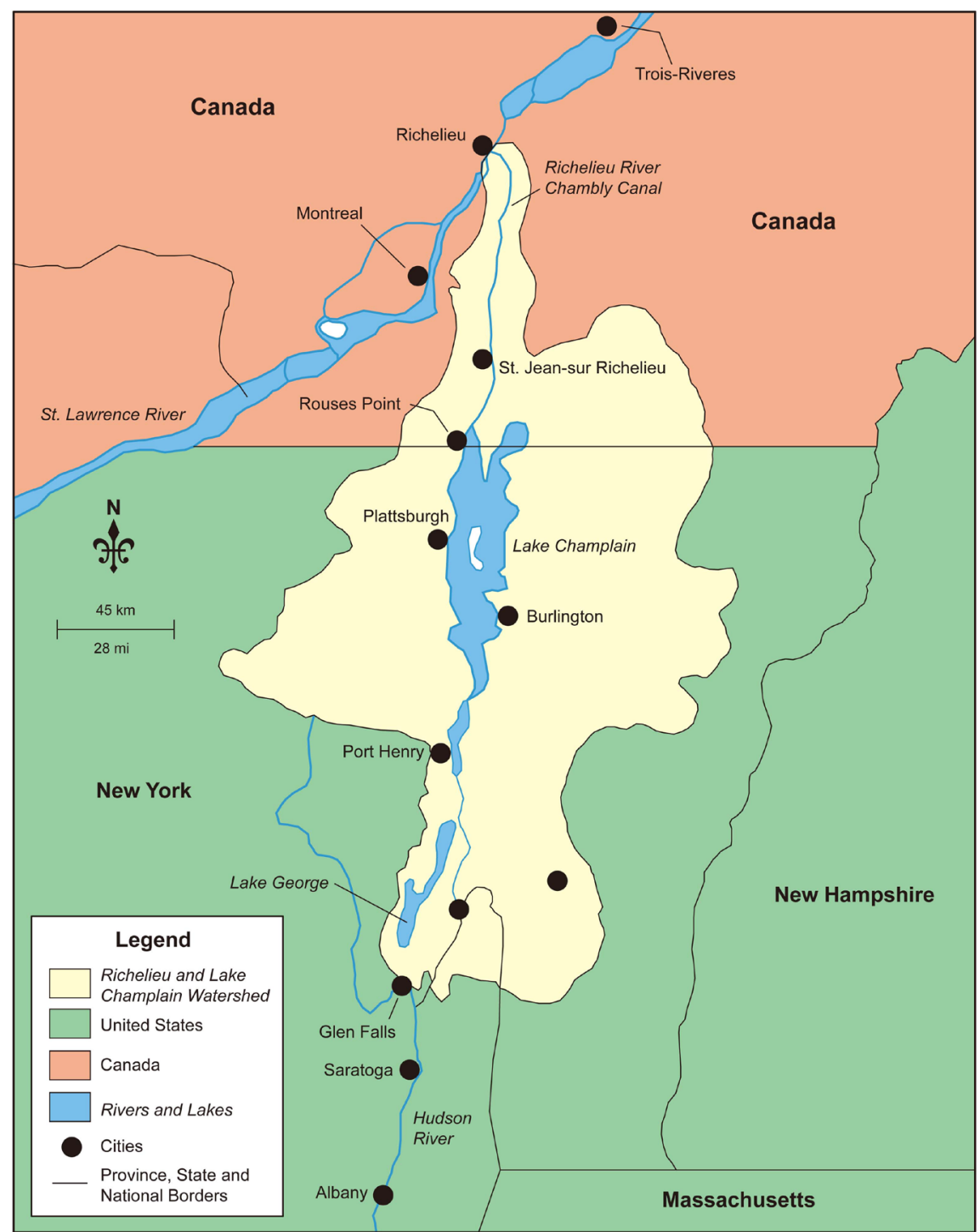

Figure 6. The Lake Champlain, Richelieu River and Chambly Canal and river watershed. Map by Mic Greenberg.

settled in a pattern of narrow strips fronting the river [1]. Industry began near Trois-Rivieres where bog iron was exploited in 1757. Most of the Quebec population lives on the St. Lawrence River Valley lowlands.

The primary objectives of the paper are: 1) to document the geological and landscape properties of the St. Lawrence River basin has contributed to the successful resource and economic development of a historically-rich region of North America and 2) to document the environmental and natural resource risks to the St. Lawrence River basin and the Gulf of Saint Lawrence estuary. These environmental challenges include the settlement of millions of people in the St. Lawrence River basin, navigation of the St. Lawrence River, disposal of treated and untreated wastewater, water pollution, shore erosion as a result of high water levels in the Great Lakes and connecting rivers, invasive species, and flooding. 


\section{Study Site}

\subsection{Geological History of St. Lawrence River Basin}

The Laurentide Ice Sheet was massive and covered millions of square kilometers including a large portion of northern United States and much of Canada. The massive sheet occurred many times during Quaternary glacial epochs-from $2.588 \pm 0.005$ million years ago to the present. The last advance covered most of North America between 95,000 BP and 20,000 years BP [4]. The effects of the glacier included the gouging out of the five Great Lakes and other smaller lakes of the Canadian Shield [2]. These lakes included Lake Champlain, Lake George and the Finger Lakes of New York State.

The ice sheet was up to $3.2 \mathrm{~km}$ thick in the center and much thinner at the edges. It caused many changes to the shape, size, and drainage of the Great Lakes basin near the end of the last ice age. Lake Iroquois extended beyond the boundaries of the present day Lake Ontario. Lake Iroquois drained through the Mohawk [5] and Hudson Rivers to the Atlantic Ocean. The ultimate collapse of the Laurentide Ice Sheet is also suspected to have influenced European agriculture through the rise of sea levels. Labrador ice flowed into the Gulf of Saint Lawrence completely covering the Maritime Provinces of Canada.

The details of the lowland's present landscape are the result of the last continental glaciation. Glaciation was followed by marine submergence, emergence and river erosion and deposition. Earlier glacial evidence was often removed by later glacial events. These glacial events were separated by a non-glacial interval during which peat and lake sediments accumulated. The last interval ended 70,000 to 34,000 years ago. Deposits exposed in valleys near Lac Saint-Pierre indicated an early interval of weathering and deposition of river gravels followed by 2 or more glacial events [1].

The last major glacial advance was 18,000 years ago. These ice sheets intermittently uncovering the south and southwestern parts of lowlands. These uncovered sections were inundated by post-glacial lakes. The residual glacial ice near Quebec obstructed the St. Lawrence Valley until 13,000 years ago when the ice disintegrated. From 13,000 to 10,000 years ago the St. Lawrence Lowland rose rapidly (up to $0.2 \mathrm{~m}$ per year) in response to the melting of the heavy ice mass and subsequent runoff [1]. The relict strand lines of the Champlain Sea on the north side are at $330 \mathrm{~m}$ and only $255 \mathrm{~m}$ on the south side.

The sea, with a surface at $40 \mathrm{~m}$ above current sea level, withdrew 9,500 years ago and occupied the central part of the basin. It drained when the St. Lawrence River eroded its channel past Quebec about 6500 years ago. The Paleozoic sediment rocks (sandstone, dolomite, limestone and shale) are 520 to 480 million years old [4]. The lowland is part of a rift valley originating in historical (Cretaceous) times and is a region of high earthquake probability where major damage can be expected.

The Champlain Valley is the northernmost unit of a landform known as the Great Appalachian Valley. The Champlain Valley is a physiographic section of 
the St. Lawrence Valley. Lake Champlain is in the Lake Champlain Valley (Figure 6) between the Green Mountains of Vermont and the Adirondack Mountains of New York which drain northward by the $171 \mathrm{~km}$ Richelieu River (Chambly Canal) to the St. Lawrence River at Sorel-Tracy, Quebec, northeast and downstream of Montreal. It also receives water from the $51 \mathrm{~km}$ long Lake George. Approximately 250,000 people get their drinking water from Lake Champlain. It is connected to the Hudson River by the Champlain Canal, which is part of the New York State Canal system [5]. Parts or all of Lake Champlain freeze each winter.

\subsection{Newfoundland Soils}

The Newfoundland landscape is a mixture of bogs, rock outcrops, barrens, water bodies (Figure 7) and mineral soils. Much of the interior of the island portion of the province is covered by extensive bogs and barren lands. These sparsely forested heather and mass barrens result from wind exposure, humid conditions, temperature limitations and soil conditions. The soils on the uplands are coarse, usually quite stony, have firm to compact subsoil and are usually very shallow [6].

The natural vegetation, boreal forest which surrounds the barrens is dominantly coniferous species including spruce and broad-leaved deciduous trees such as birch. The deeper and more favorable soils are usually found on elevated ridges, on coastal lowlands and along river terraces. Newfoundland soils are very acid, and low fertility is the dominant soil limitation to crop growth. The soils require lime and fertilizer to supplement elements necessary for plant growth. Another major limitation is stoniness, which creates management problems and increases the cost of land clearing. Wet soils need to be drained prior to agricultural

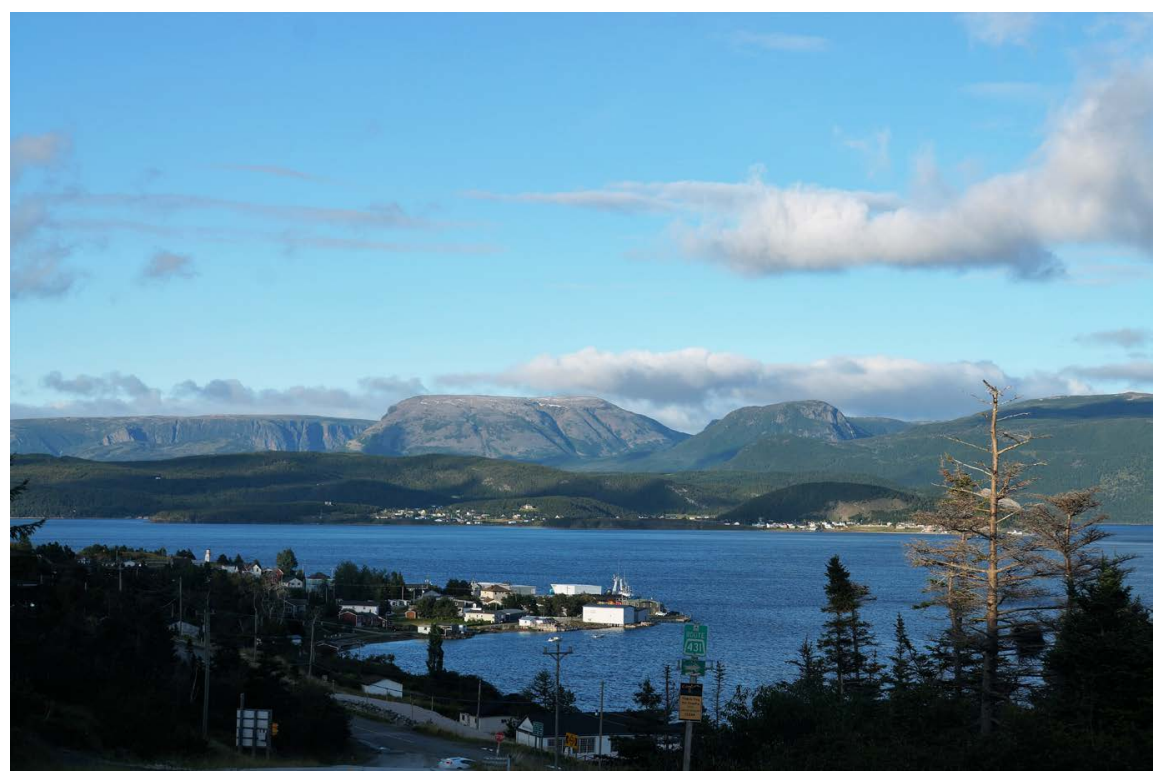

Figure 7. The Bonne Bay community out letting into the Gulf of Saint Lawrence. Picture taken by Lois Wright Morton. 
use. Compacted subsoil layers resist root penetration and slow rainfall percolation. Steep slopes and complex topography prevent the use of farm machinery and create an erosion hazard.

The Newfoundland Exploratory Soil Survey Program ended in the mid-1990s and was the basis for the Canada Land Inventory Soil Capability Mapping [6]. The exploratory soil survey provided critical data for planning long term agricultural priorities. A detailed soil survey of Newfoundland was needed to provide soil information to guide agriculture use to the most suitable areas, and also for land management planning.

\subsection{Gulf of Saint Lawrence}

The Gulf of Saint Lawrence is the outlet for the North American Great Lakes water (Figure 2) via the St. Lawrence River. The gulf is a semi-enclosed sea, covering about $226,000 \mathrm{~km}^{2}$ of area with $34,500 \mathrm{~km}^{3}$ of water, and having an average depth of $152 \mathrm{~m}$ [3]. The Gulf of Saint Lawrence adjoins the provinces of New Brunswick, Nova Scotia, Prince Edward Island, Newfoundland and Labrador and Quebec. Seven major rivers flow into the Gulf of Saint Lawrence including St. Lawrence River, Miramichi River, Natashquan River, Romaine River, Restigouche River, Margaree River and the Humber River. There are 7 bays, and the Gulf of Saint Lawrence flows into the Atlantic Ocean through 3 outlets, the Strait of Belle Isle, the Cabot Strait (Figure 8), and the Strait of Cansoc.

\subsection{Strait of Belle Island}

The Strait of Belle Isle is a waterway in eastern Canada that separates the Labrador Peninsula and the island of Newfoundland (Figure 2). The strait is the northern outlet for the Gulf of Saint Lawrence and is considered part of the

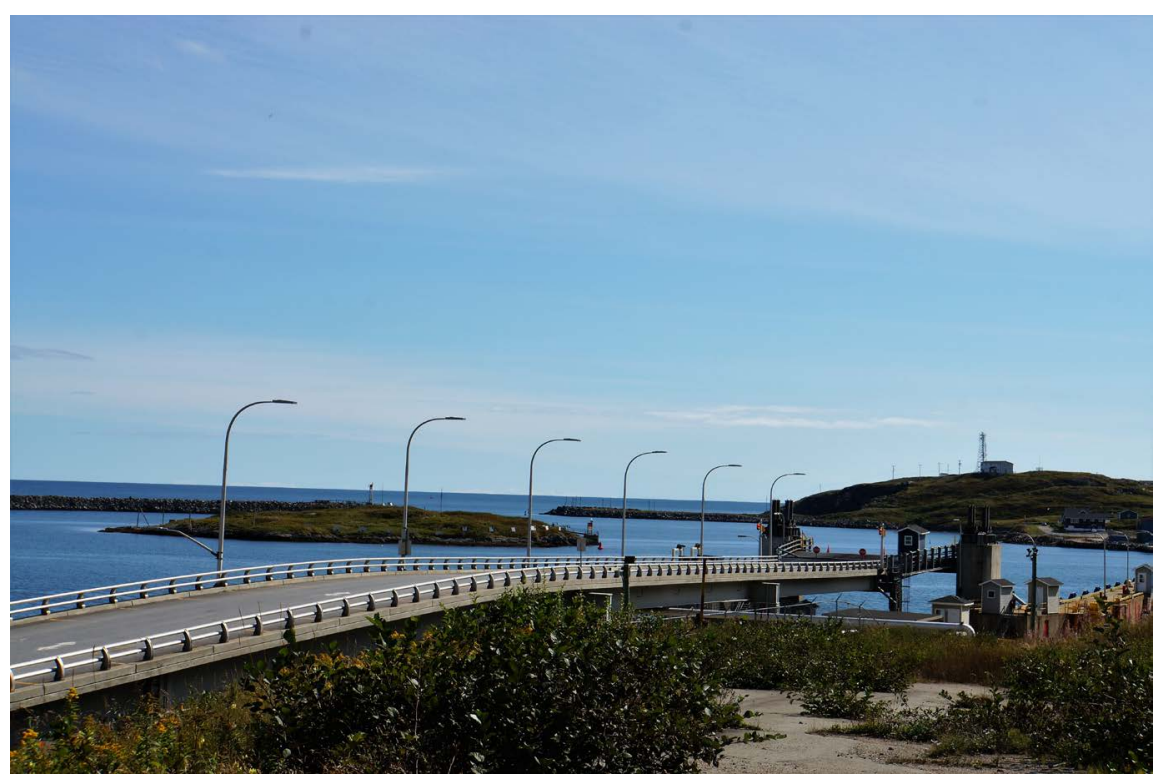

Figure 8. The Gulf of Saint Lawrence estuary at the Port of Basqusat on Newfoundland near the Cabot Strait and the Laurentian Channel. 
Great Lakes-St. Lawrence Seaway system. The strait is $125 \mathrm{~km}$ long and ranges in width from 15 to $60 \mathrm{~km}$. Navigation in the strait [7] can be extremely hazardous with the Labrador Current interacting with strong tidal currents. Depths can reach several hundred meters. Sea ice is present for 8 to 10 months with gale force winds and fog. The sea ice prevents year-around shipping. A ferry service operates in the western part of the strait between St. Barbe, Newfoundland and Blac Sablong, Quebec (Figure 2).

\subsection{Cabot Strait}

Cabot Strait is located between Cape Ray, Newfoundland and Cape North, Cape Breton Island. It is the widest of 3 outlets for the Gulf of St. Lawrence into the Atlantic. The other outlets are the Strait of Belle Isle and Strait of Canso. The Laurentian Channel is a deep trench in the Cabot Strait (Figure 8) with the shallow coastal waters closer to Newfoundland and Cape Breton Island. These depth changes in Cabot Strait have caused rogue waves. The strait was a strategically important waterway all throughout the history of both Canada and Newfoundland. The strait is an important international shipping route [7], being the primary waterway link between the Atlantic and the Great Lakes and St. Lawrence Seaway. The Cabot Strait has a maximum depth of $550 \mathrm{~m}$ over the Laurentian Channel. The maximum length of the Cabot Strait is $37 \mathrm{~km}$ and the maximum width is $130 \mathrm{~km}$.

\subsection{Laurentian Channel}

The Laurentian Channel is a deep trench in the Cabot Strait and a deep submarine valley off the coast of eastern Canada in the Gulf of Saint Lawrence (Figure 2 ). The channel is of glacial origin and is the submerged valley of the historic St. Lawrence River, running $1400 \mathrm{~km}$ from the confluence of the St. Lawrence River with the Saguenay River. It runs past Anticosti Island and through the Gulf of Saint Lawrence to the edge of the continental shelf off the island of Newfoundland. The historic Laurentian fan is located at the edge of the continental shelf. The channel depth ranges from 180 to $550 \mathrm{~m}$ with shallow sub-tidal shelves on each side of the channel ranging in depths of less than $100 \mathrm{~m}$. The Laurentian Channel has a minimum width of $10 \mathrm{~km}$ and can be as much as $55 \mathrm{~km}$ wide. The steep slope of the Laurentian Channel was the site of a 1929 Grand Banks earthquake which created a tsunami that destroyed communities in Newfoundland and Cape Breton Island.

\subsection{Newfoundland}

Newfoundland is a large Canadian island of the east coast of North America (Figure 2). This island blocks the mouth of the St. Lawrence River creating the world's largest estuary, the Gulf of Saint Lawrence. Newfoundland is the world's $16^{\text {th }}$ largest island with an area of $108,860 \mathrm{~km}^{2}$. The first inhabitants of Newfoundland were the Paleo-Eskimo. The island was settled by indigenous peoples 
of the Dorset culture about 4,000 years ago. It was visited by Leif Eriksson, an Icelandic Viking, in the $11^{\text {th }}$ century who call the island Vineland (Figure 9). The next Europeans to come were the Basque, Spanish, Portuguese, French and English migratory fishermen and whalers [1].

Sir Humphrey Gilbert claimed Newfoundland as England's first overseas colony in 1583 under Royal Charter of Queen Elizabeth I of England. Newfoundland is the British Empire's oldest colony. The site is one of the earliest meetings of the Old World and the New World. At the time of English settlement the Beothuk who had migrated from Labrador, occupied the island since the time of Norse visits. L'Anse aux Meadows was a Norse settlement (Figure 10) near the northernmost tip of Newfoundland and dated 1000A.D. [1].

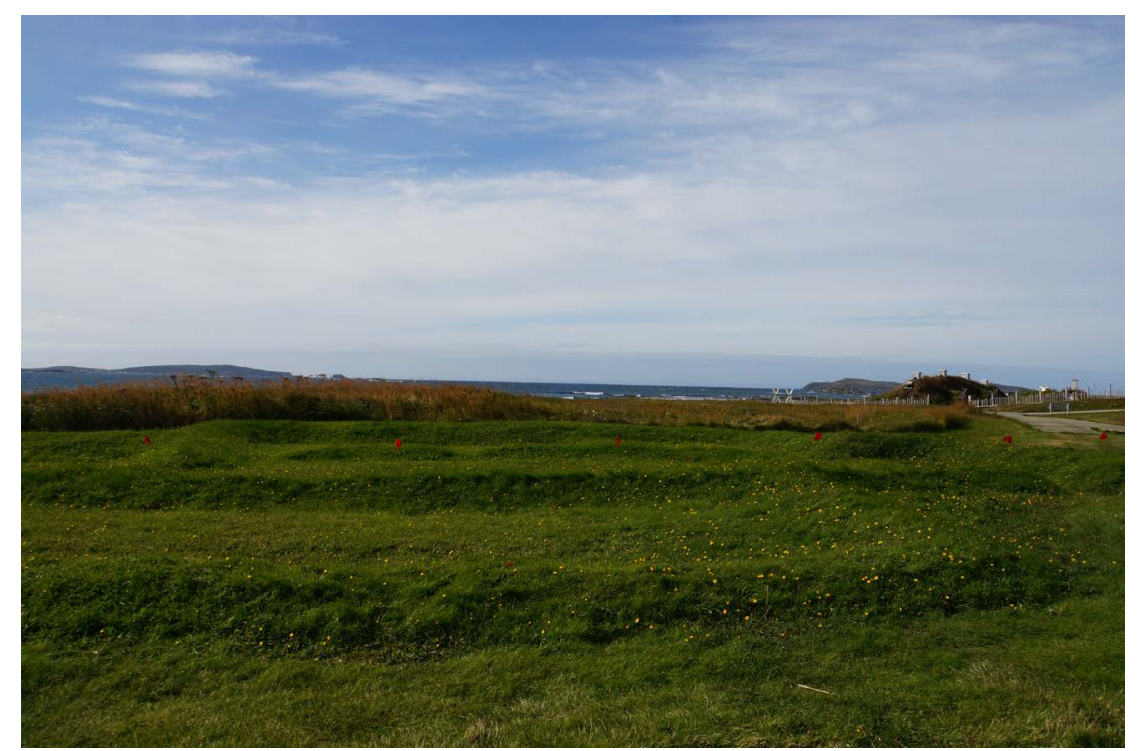

Figure 9. The Norse settlement site (1000AD) near St. Antony and adjacent to Atlantic Ocean. The building sites appear as raised ridges. The site is now L'Anser aux Meadows National Historic Site. Picture taken by Lois Wright Morton.

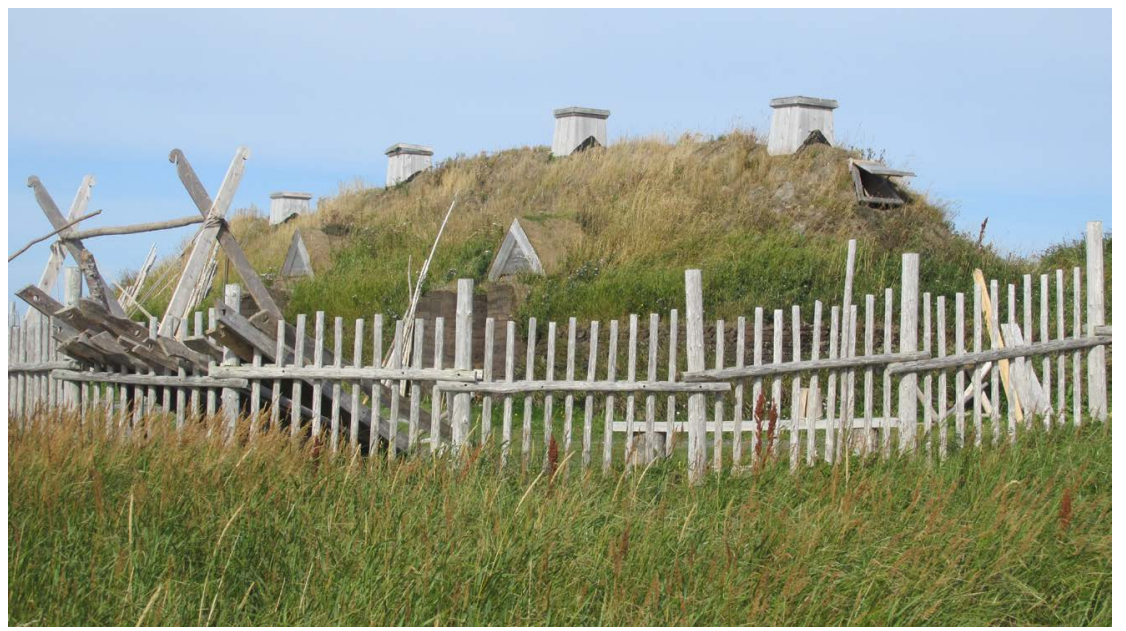

Figure 10. The building site appears as a recreated sod hut. The site is now L'Anser aux Meadows National Historic Site. Picture taken by Lois Wright Morton. 
The Norse (Leif Eriksson) explored the Gulf of Saint Lawrence in the $11^{\text {th }}$ century (Figure 11), and European mariners (John Cabot, Gaspar brothers, Miguel Corte-Real, and Alonso Sanchez) in the $15^{\text {th }}$ and early $16^{\text {th }}$ century. In 1535 Jacques Cartier, was the first European explorer known to have sailed the St. Lawrence River. The Basques were the first Europeans to fish and hunt whales on the St. Lawrence River and Gulf of Saint Lawrence and to set up settlements and trade with the indigenous Americans. Basque commercial and fishing activity reached its peak in 1588. The Spanish destroyed most of the Basque whaling fleet in 1588. In the $17^{\text {th }}$ Century the French controlled the St. Lawrence River and adjacent lowlands. In 1758 the British captured New France during the Seven Year's War [1].

Because of Lachine Rapids (Figure 12), which were impassable, the St. Lawrence was only navigable as far west as Montreal (Figure 13). In 1829, the Lachine Canal completion allowed ships to pass through the rapids. An extensive system of locks and canals, the St. Lawrence Seaway was officially opened on 26 June 1959 by Elizabeth II representing Canada and President Dwight D. Eisenhower representing the United States. The St. Lawrence Seaway permits ocean-going ships to travel all the way to the southwest corner of Lake Superior [2].

During WWII between 1942 and 1944, German U-boats sank several merchant marine ships and three Canadian warships in the lower St. Lawrence River, the Strait of Belle Isle and Cabot Strait and the Gulf of Saint Lawrence. Many of these sunken ships still lie on the river and estuary floor with varying environmental impacts depending on the cargo and any recovery operations.

During the 1970s and after more than 150 years of successful resource and

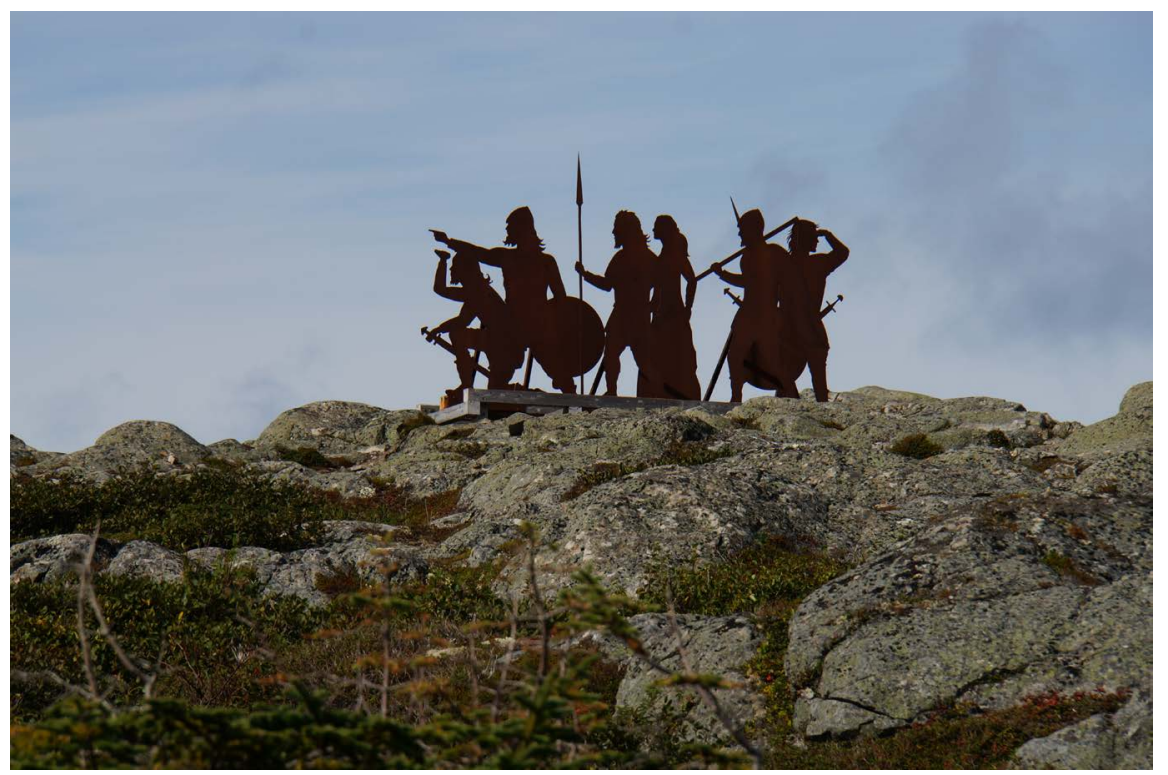

Figure 11. The monument that Norway gave Canada to recognize the Norsemen trading post at L'Anser aux Meadows National Historic Site. Picture taken by Lois Wright Morton. 


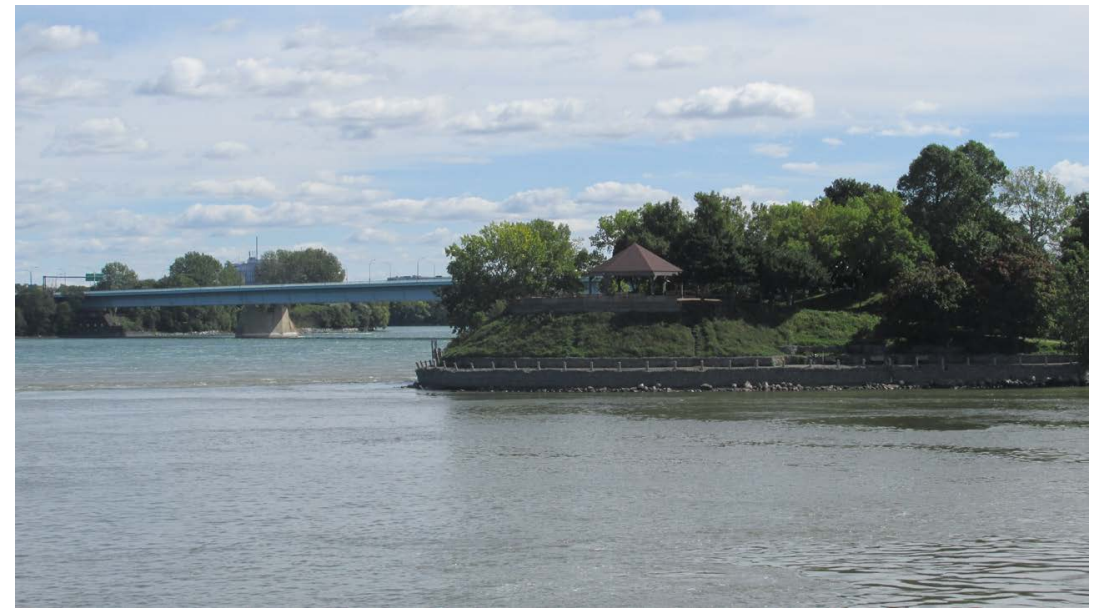

Figure 12. Montreal harbor located just east and down river from the Lacline Rapids. Picture taken by Lois Wright Morton.

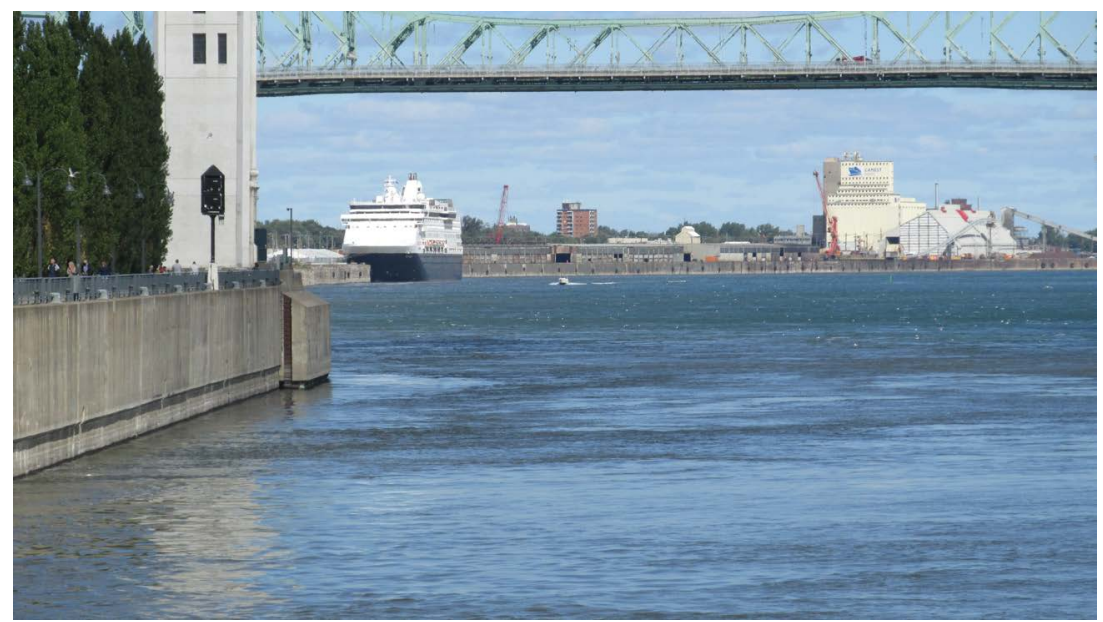

Figure 13. A cruise ship on the St. Lawrence River canal near Montreal.

economic development of the St. Lawrence Basin a grass roots challenge of the proposed United States Army Corps of Engineers (USACE) planned development of the St. Lawrence River was blocked by a successful ecological campaign called "Save the River". Save The River is a member of the Waterkeeper Alliance as the Upper St. Lawrence River keeper. Since 1978 Save The River has worked with thousands of year-round and seasonal members, on both the U.S. and Canadian sides of the River, to ensure that the upper St. Lawrence River is protected for future generations. Since 1978, the organization has worked tirelessly to protect the St. Lawrence River for future generations. Working with members in both the U.S. and Canada, Save The River has been carrying out its mission of restoring, preserving and protecting the river through advocacy, education and research. Their web site is: http://www.savetheriver.org/.

\subsection{Gander International Airport}

Gander, a town of 10,000 people in Newfoundland, played an important role 
during the 9/11 terrorist attacks. The September 11, 2001 attacks were a series of four coordinated attacks by al-Qaeda an Islamic terrorist group against the United States. The attacks resulted in 25,000 long-term injuries and 2977 fatalities. The incident also resulted in the death of 343 firefighters and 72 law enforcement officers. Nineteen al-Queda terrorists hijacked four commercial airplanes. Two planes crashed into the World Trade Center in Lower Manhattan, New York City. Another crashed into the Pentagon in Arlington County, Virginia and the fourth plane crashed in a field in Stony Creek, Pennsylvania after passengers attacked the hijackers. The flight was headed to the Washington D. C. the nation's capital. The World Trade Center towers were removed and replaced. The Pentagon building was repaired. A monument was created at the Pennsylvania crash site.

On September 11, 2001 United States airspace was closed and Canadian air traffic controllers quickly landed as many flights from Europe as possible. Gander International Airport (Figure 14) is the first sizable airport on the northeast corner of the North American continent and has long served as a refueling stop for trans-Atlantic flights. The town therefore played host to 6700 airline passengers on 38 planes stranded due to the $9 / 11$ terrorist attacks. Buildings in Gander were quickly converted into makeshift shelters including the elementary school and private homes. Food was provided to passengers from almost 100 countries. Gander's hospitality (Figure 15) to the unexpected 9/11 house guests inspired a Broadway musical and has drawn many worldwide accolades.

\subsection{St. Lawrence Valley}

Much of the St. Lawrence lowland is underlain by clay deposited in the Champlain Sea. These marine clay deposits were up to $60 \mathrm{~m}$ thick on the north side near the former glacial margin, and thin to the south. When rain or snow melt

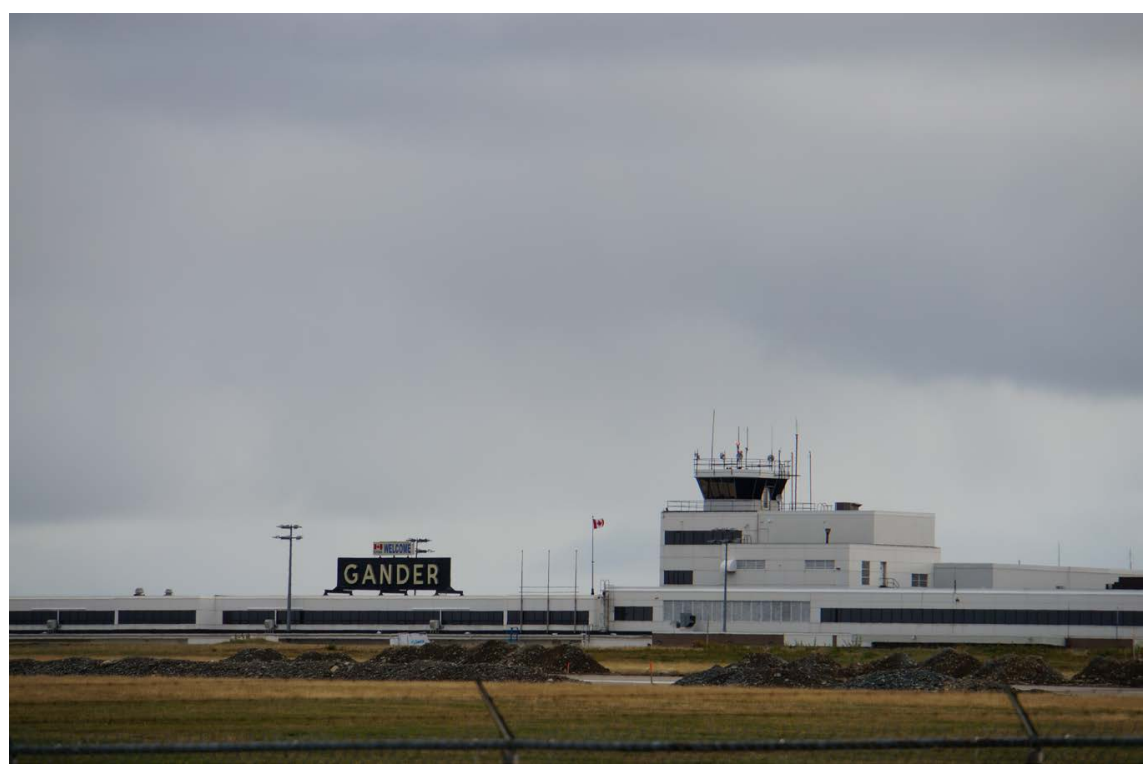

Figure 14. Gander airport where 37 planes landed hours after 911. 


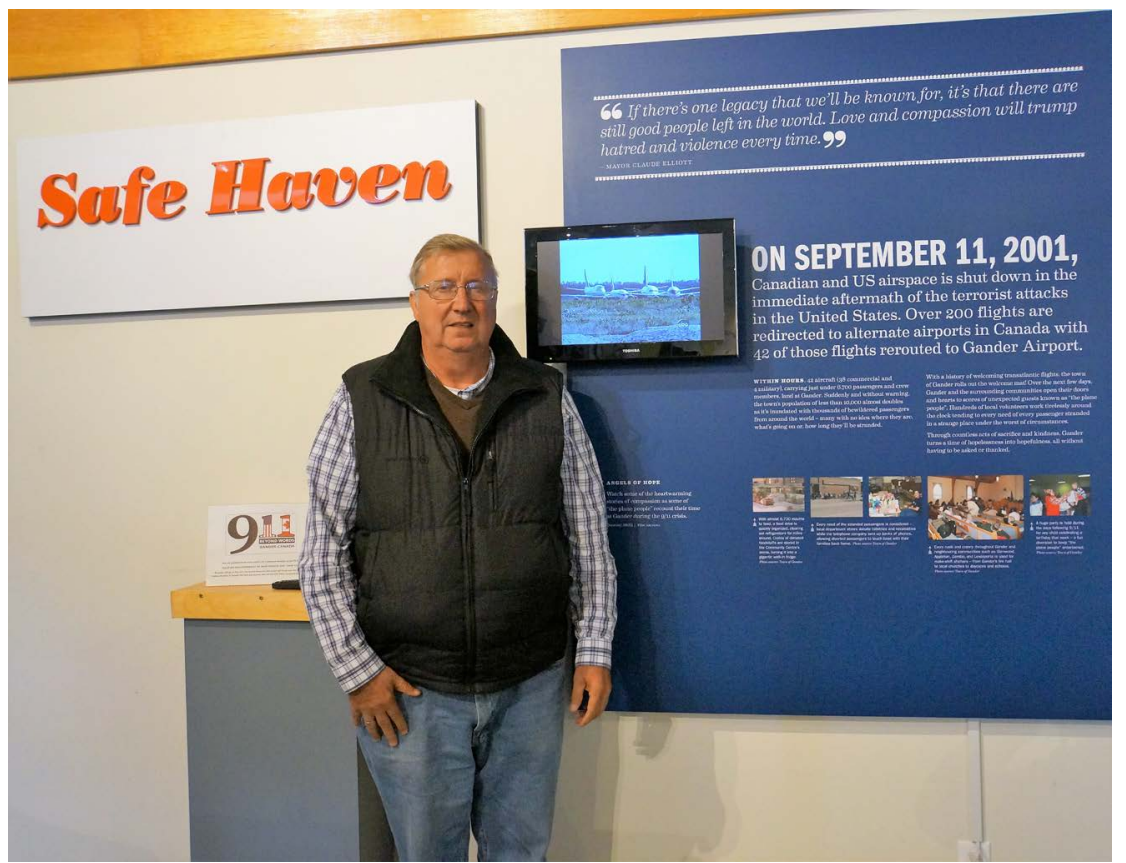

Figure 15. The Gander museum with photographs, letters and artifacts from three hundred 09/11 visitors.

generates runoff, the saturated clay becomes unstable and often subsides in earth-flow landslides, which have caused much loss of life and property. The west and south parts of the lowlands are underlain by glacial deposits (till) rather than marine clay. Wave action has removed the silt and clay from the till, leaving behind sand and gravel [8].

Fossils are abundant in the Champlain Sea deposits, often containing vertebrates such as seals and wales, as well as mollusks that are similar to those found on the Gulf of Saint Lawrence (Labrador) coast (Figure 2). In the lower, central part of the lowlands, areas of sand north and east of Montreal, are remnants of the former Ottawa and St. Lawrence River deltas. Some of the low terraces are covered by river sands and windblown sand dunes, some of which are $18 \mathrm{~m}$ high. The Aeolian sand is stabilized by vegetation. Much of the lowlands have good agricultural soils are often clayey and need tile drainage. The clay has been used for brick and tile manufacture, while sand and gravel deposits are exploited for road and construction materials. The rocks of the lowlands have been quarried for building stone, silica, cement, lime, and crushed stone for making of concrete, brick and tile [8].

\subsection{Lake Champlain}

Lake Champlain was named after French explorer Samuel de Champlain, who visited it in 1609. Lake Champlain is a natural freshwater lake within the borders of the United States (Vermont and New York) (Figure 6) and the Canadian province of Quebec. Most of the New York area is part of Adirondack Park. There are recreational opportunities in the park along the mostly undeveloped 
shore of Lake Champlain. The cities of Plattsburgh, New York, and Burlington, Vermont, are on the lake's western and eastern shores. The lake is $263 \mathrm{~km}$ long with a maximum width of $22 \mathrm{~km}$. The average depth is $19.5 \mathrm{~m}$ with a maximum depth of $122 \mathrm{~m}$. The shoreline is $945 \mathrm{~km}$. The water volume is $25.8 \mathrm{~km}^{3}$ and the watershed is $21,326 \mathrm{~km}^{2}$. Lake Champlain outflows to the Richelieu River and Chambly Canal in Canada (Figure 6).

\subsection{Invasive Species}

Invasion of the Great Lakes by sea lampreys (Petromyzon marinus) occurred in 1919 after improvements to Welland Canal and overfishing resulted in a decline in native trout [2]. This led to an increase of another invasive species, alewife (Alosa pseudoharengus), and predators were introduced including Salmonids (Salmonidae), brown trout (Salmo trutta), steelhead, (Oncorhynchus mykiss) coho (Oncorhynchus kisutch) and chinook salmon (Oncorhynchus tshawytscha) to control alewife [2]. The Great Lakes restoration program was successful and trout and salmon exploded creating a large sport fishery.

\subsection{History of St. Lawrence Seaway}

In 1535, French explorers were the first recorded Europeans to push upstream in the great river to the future site of Montreal. The enormous rapids and falls to the west prevented further inland movement. Later, French fur traders pushed west through the rapids by using canoes and portaging. After 1763, the British took Canada from the French. Later, a series of narrow canals with locks were built to circumvent the falls and rapids. The first canal to open along the future "seaway" to Lake Superior, the Welland Canal, was built to avoid the Niagara Escarpment and Niagara Falls, or where Lake Erie drains through Niagara River into Lake Ontario. In 1833, the Welland Canal opened in Canada and paralleled the Niagara River in New York State [2]. The Welland Canal accommodated ships up to $113 \mathrm{mt}$ pulled by horses that walked on a towpath. One Canadian goal was to take trade away from the Erie Canal built in 1825 [5], but actually supplemented the New York State waterways. Great Lakes shippers often used the Oswego Canal as an alternative route from Lake Ontario to New York City via the Oswego lateral canal, Erie Canal, Mohawk River and Hudson [5]. Although the route involved the added expense of moving cargo from large ocean going ships to smaller canal barges at Oswego, the Oswego River (Figure 16) and Oswego canal were a more direct route to New York City and the Atlantic Ocean, and also avoided the canal around the Lachine rapids on the St. Lawrence River west of Montreal. So, if Canada hoped to challenge New York City's hold on the western trade, a ship canal around the Lachine rapids near Montreal was a must [7].

By 1848, the difficulties of river current, rocky soil, influence peddling, and labor problems were overcome, and a series of locks and short canals with a water depth of $2.7 \mathrm{~m}$ were constructed, and trip time from Lake Erie to Montreal 


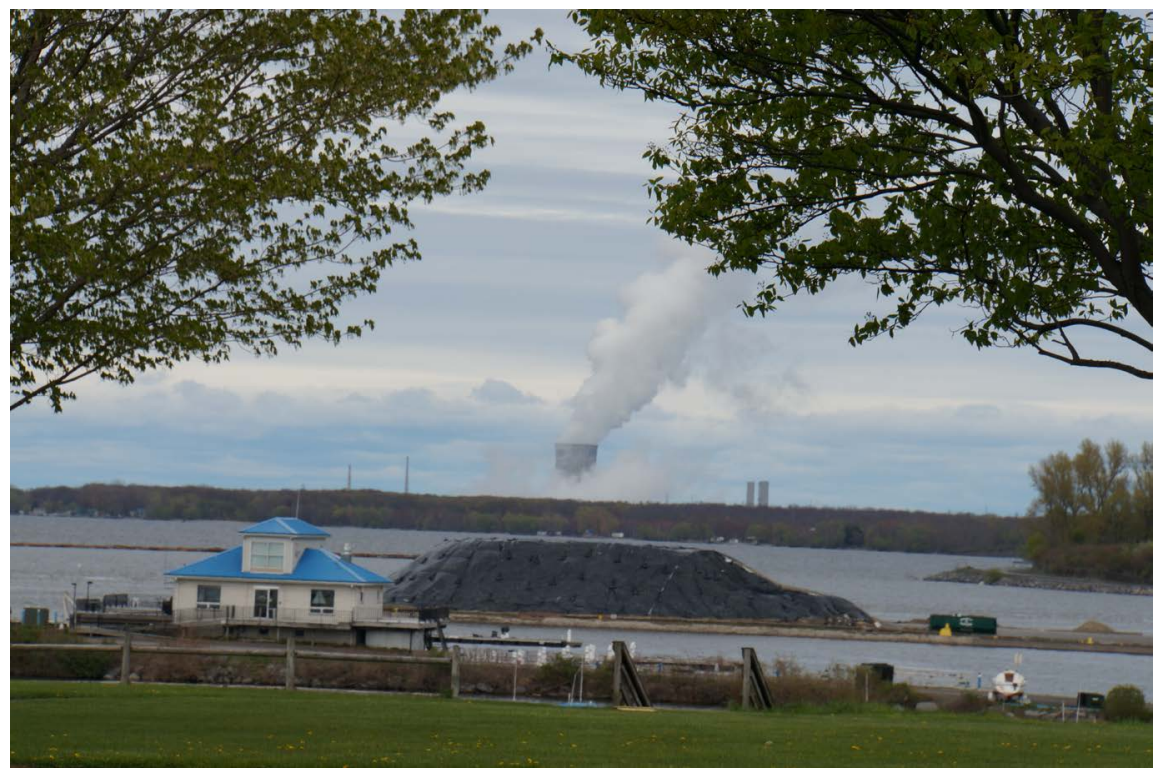

Figure 16. Oswego Port at the mouth of the Oswego River and canal. Nuclear power plant cooling tower is in background.

on the waterway was reduced [7]. However, Montreal still did not supplant the ice-free New York City port as North America's principal link with Europe (Figure 13).

The Lachine rapids offered an unanticipated opportunity for a tourist attraction. Small steamers loaded with thrill seekers would leave upper river ports to run downstream through the huge Lachine rapids on the St. Lawrence River near Montreal. The ships then used the canals on the return trip. After the locks and canals were created the rapids were traversed from the west for over 100 years by double hull steel boats as a thrill ride. More than 100,000 passengers took the trips each year and some boats crashed into the rocks and sunk. The sport started in 1850 and lasted for almost 100 years. There were often steering gear breaks, which caused ships to be out of control and run aground. Joint locks linking Canada and United States are managed by the Saint Lawrence Seaway Development Corporation. Sections of the St. Lawrence River occurring in Canada and downstream from Montreal are regulated by offices of Transport Canada in Port of Quebec.

The St. Lawrence Seaway is a maze of canals, locks and channels in the US and Canada that permit ocean-going vessels to travel from the Atlantic Ocean to the Great Lakes of North America, as far west as Duluth, Minnesota on southwest end of Lake Superior [7]. Legally, the Seaway extends from Montreal, Quebec, to Lake Erie which is connected to Lake Ontario by the Welland Canal. The upstream section is not a continuous canal, and, rather, consists of several stretches of navigable channels within St. Lawrence River. There are a number of locks and canals along the banks of the St. Lawrence River to bypass several rapids and dams [1].

In 1871, the St. Lawrence River locks allowed the transit of vessels up to $57 \mathrm{~m}$ 
long, $13.56 \mathrm{~m}$ wide and drafting less than $2.7 \mathrm{~m}$. The first Welland Canal (Figure 4) was constructed from 1824-1829, and had a lock size of $46 \mathrm{~m}$ in length, $8.1 \mathrm{~m}$ wide and 2.7 deep [5]. The Welland Canal was enlarged 3 more times with the current (fourth) Welland canal locks being $233 \mathrm{~m}$ long, $24 \mathrm{~m}$ wide and $9.1 \mathrm{~m}$ deep.

In 1895, the US and Canada jointly appointed a Deep Waterway Commission to recommend navigation routes between the Atlantic Ocean and the Great Lakes-the first cooperative international board to study the possibility of a seaway. The initial effort was extended by the Boundary Waters Treaty of 1909, which deferred the right of both nations regarding navigation of boundary waters and also created an International Joint Commission. Twelve years later, the International Joint Commission recommended Canada and the US jointly improve the St. Lawrence River from Lake Ontario to Montreal [7]. This cooperation lead to the signing of the St. Lawrence Treaty in 1932, in which both nations agreed to equally share construction costs of the waterway from the Atlantic Ocean all the way to Lake Superior (Figure 1). Any electric power generated by the project (Figure 17) also would be equally shared. However, the United States Senate did not ratify the treaty. The outbreak of WWII brought about renewed interest in the project, and a new treaty was written in 1941. This $2^{\text {nd }}$ attempt met the same fate in the Senate as the earlier treaty, as did a 1947 proposal that provided for the collection of tolls to pay the cost of construction. Resistance for this proposal was primarily from states on the East and Gulf coasts. The breakdown of the negotiations caused New York State and Ontario to open talks for the development of the St. Lawrence River. Finally in 1954, the US agreed to joint development, with both nations participating in the construction of a seaway in the international section of St. Lawrence River and Great Lakes. Support from President

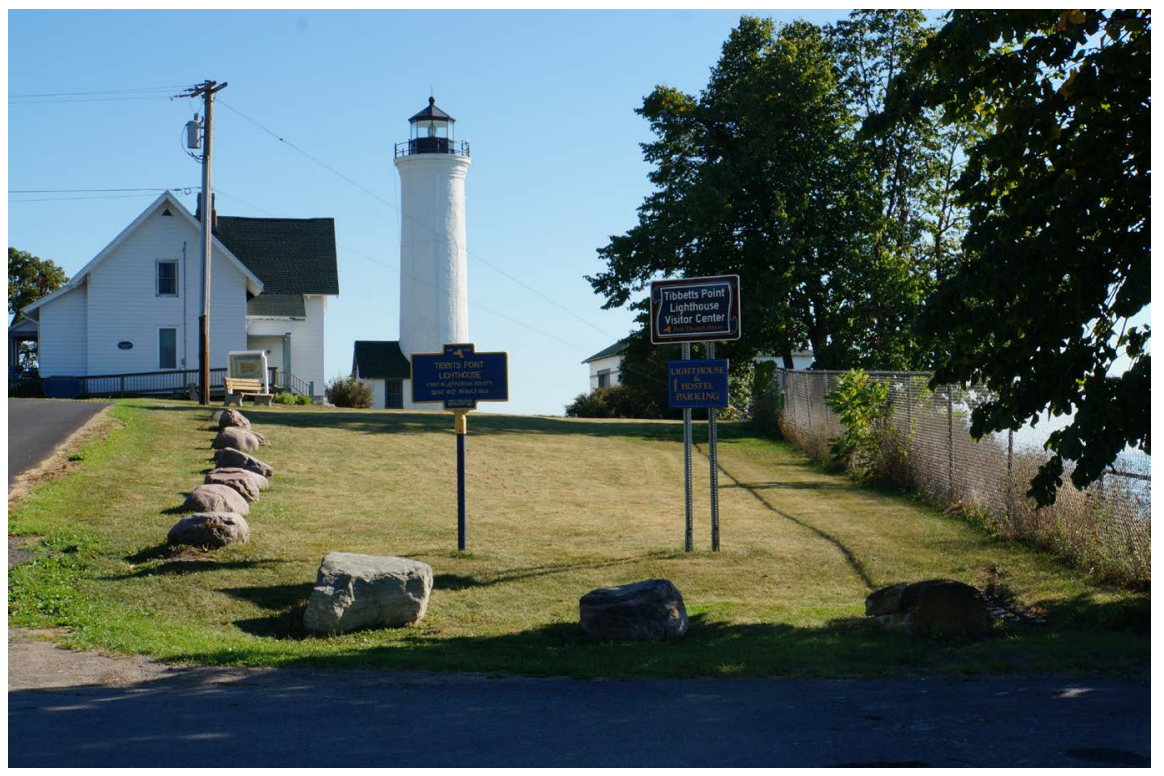

Figure 17. Tibbetts Point Light House. Near the Town of Cape Vincent near the mouth of the St. Lawrence River. 
Eisenhower and American steel companies facilitated the agreement. Discoveries of iron ore in Labrador, spurred the steel companies to support as the St Lawrence Seaway could transport Labrador ore to the United States mills in the Great Lakes region.

The necessity for minimum $8.2 \mathrm{~m}$ navigation depth and the $262 \mathrm{~m}$ long locks for Seaway vessels helped drive the costs for the Montreal to Lake Ontario section of the seaway to $\$ 124$ million for the United States and \$285 million for Canada. Part of the money was used to relocate tribal villages along the project route which was completed in 1958. The St. Lawrence Seaway has had an impact on many US Border States and Canada. The commercial and environmental impacts include the discharge of industrial and wastewater into the St. Lawrence River centered on the Thousand Islands (Figure 18) located east of Lake Ontario and west of the Iroquois Lock and control dam on the St. Lawrence River (Figure 8) which controls the water level in the Thousand Islands area and the flow rate into the river. Many of the islands are shallow to bedrock and present a wastewater treatment challenge. Ogdensburg, New York, where Reynolds Aluminum and General Motors both built plants. Oswego, Rochester and Buffalo felt the economic and environmental impact. The construction of large power-producing dams on the St. Lawrence River resulted in a land use change and had an environmental impact including the water, air, and land pollution.

The Seaway's power dams serve New York State, New England and parts of Canada, and produce 3.5 million kilowatts of electricity. The Moses-Saunder Dam (Figure 19) between New York State and Ontario is one of the largest power-producing dams in the world, with a 1.9 million kilowatt capacity. In addition to heavy industrial consumption, St. Lawrence electricity became available

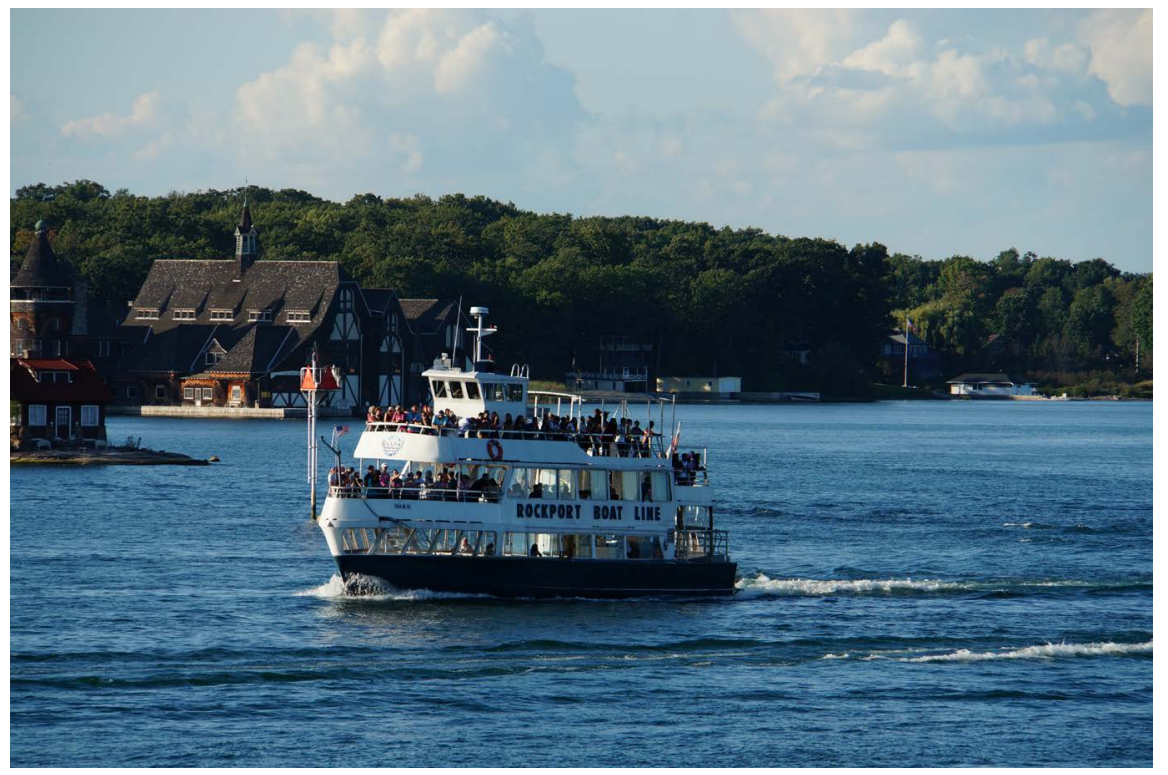

Figure 18. Thousand Islands area just east of where Lake Ontario flows into the St. Lawrence River. The water level is maintained by a lock and dam to the east of the Thousand Islands area. 


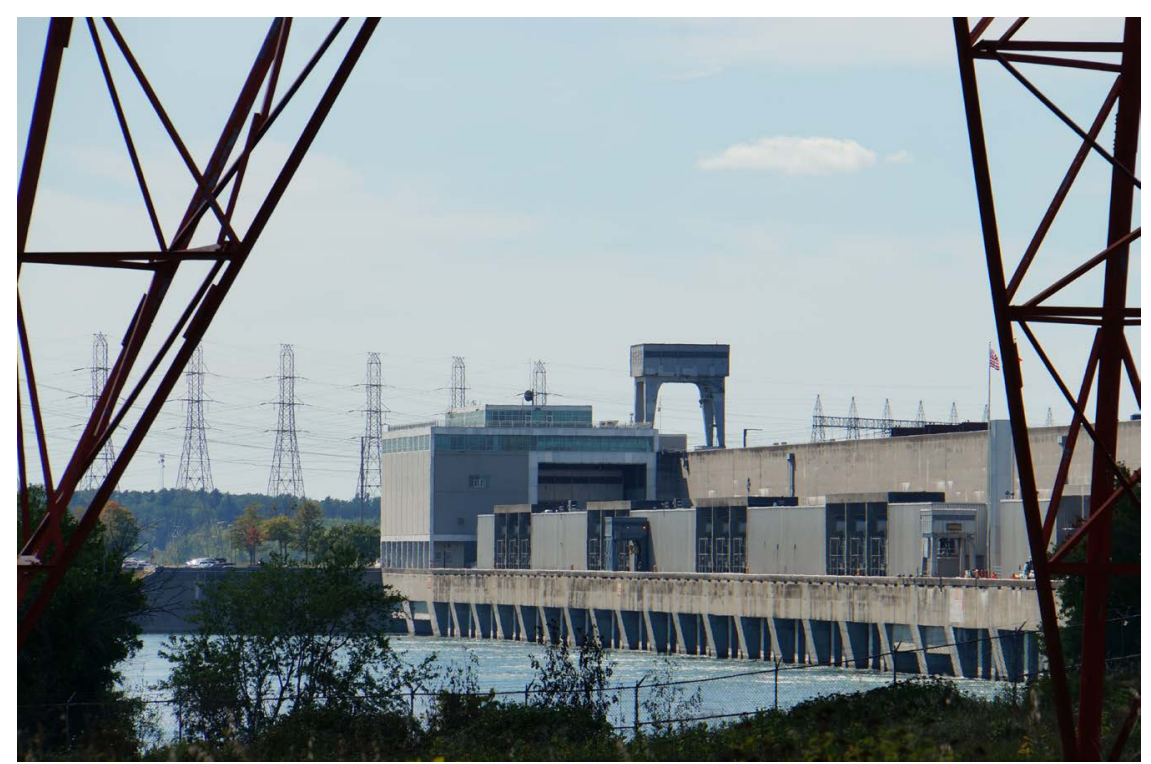

Figure 19. The Moses-Saunder Dam hydroelectric dam. The electricity is shared equally between the New York and Canada.

to 600,000 residential consumers and as far south as Albany and Oswego, New York. It took two centuries to improve navigation on the St. Lawrence River and along the St. Lawrence Seaway.

\section{Summary and Conclusions}

The St. Lawrence Seaway has provided the pathway for settlement of Canada, and is intimately tied to the development of the northeastern portion of North America. The Strait of Belle Isle was the entry way for the Norse people to visit Newfoundland more than 1000 years ago, allowing the first known Europeans to explore North America. The St. Lawrence River and the Gulf of Saint Lawrence with the Laurentian channel became the explorer, navigation and settlement pathway that lead to the economic development of Canada.

The Gulf of Saint Lawrence and the Cabot Strait benefited from the presence of the historical St. Lawrence River Valley, buried by rising sea water after the ice age, known as the Laurentian channel. This unique, deep channel became the shipping lane for ocean going ships between the Great Lakes and the Atlantic Ocean. The Lachine rapids near Montreal historically blocked ocean-going ships from the Great Lakes. Canals were dug around the rapids to permit ships to enter the Great Lakes via Lake Ontario (Figure 13). The Welland Canal and locks connected Lake Ontario with Lake Erie. Lake Erie was connected naturally to Lake Huron via the Detroit and St. Clair River, Lake Clair and the Detroit River, while Lake Huron connects via the Straits of Mackinac to Lake Michigan and via the locks on the St. Mary's River to Lake Superior [2]. The navigation and shipping channel between Lake Superior and the Atlantic Ocean is now called the St. Lawrence Seaway.

The St. Lawrence Seaway was in direct competition with the New York State 
Canal system, which was a barge canal [5] and could not handle Tall Ocean going ships. Eventually, the St. Lawrence Seaway and the Erie Canal were linked by the Oswego River and Canal. Since it was shorter to go from Lake Ontario (Figure 16) to New York City via the New York State barge canals, Oswego became the home of a major harbor where ocean going ships were unloaded and cargo put on barges to be transported to New York City harbor via the Erie canal, the Mohawk River and the Hudson River. In the 1970s, planned urban development of the St. Lawrence River basin by USACE was blocked by the "Save the River" campaign. Environmental challenges to the St. Lawrence River basin include disposal of treated industrial and urban waste water, water pollution, shore erosion, invasive species and flooding.

\section{Acknowledgements}

Published with funding support from USDA, NIFA, Water Division and the Director of the Illinois Office of Research, College of Agricultural, Consumer, and Environmental Science, University of Illinois, Urbana, Illinois.

\section{Conflicts of Interest}

The authors declare no conflicts of interest regarding the publication of this paper.

\section{References}

[1] Dawson, S.E. (2010) The Saint Lawrence: Its Basin and Borderlands: The Story of Their Discovery, Exploration and Occupation. Nabu Press, Washington DC.

[2] Olson, K.R. and Miller, G.A. (2020) Managing the St. Lawrence Seaway: Western Great Lakes Basin. Journal of Water Resource and Protection, 12, 637-656. https://doi.org/10.4236/jwarp.2020.128039

[3] Arkus, M. (2014) Down the St. Lawrence, the World's Largest Estuary: Canadian Odyssey on the Looney Front-Part 21. Huffington Post.

[4] Dyke, A.S. and Prest, V.K. (1987) Lake Wisconsin and Holocene History of the Laurentide Ice Sheet. Geographie Physique et Quatemaire, 41, 237-263. https://doi.org/10.7202/032681ar

[5] Morton, L.W. and Olson, K.R. (2019) Migration and Navigation Corridor: The New York State Canal System. Journal of Soil and Water Conservation, 74, 102A-108A. https://doi.org/10.2489/jswc.74.5.102A

[6] CanSIS (1981) Newfoundland Soil Survey and Land Use Program. Government of Canada.

[7] Ellis, W.S. (1980) Canada's Highway to the Sea. National Geographic, 157, 586-623.

[8] Benke, A.C. and Cushing, C.E. (2005) Rivers of North America. Academic Press, Amsterdam, 989-990. 